\title{
New data on host-plants of grass flies of the subfamily Oscinellinae (Diptera: Chloropidae)
}

\section{Новые данные о кормовых растениях змаковых мух подсемейства Oscinellinae (Diptera: Chloropidae)}

\author{
E.P. Nartshuk ${ }^{1}$, N.Yu. Panteleeva ${ }^{2}$ \\ Э.П. Нарчук ${ }^{1}$, Н.Ю. Пантелеева ${ }^{2}$
}

\footnotetext{
${ }^{1}$ Zoological Institute of Russian Academy of Sciences, Universitertskaya nab. 1, St. Petersburg 199034, E-mail: chlorops@zin.ru

2 Voronezh State University, Universitertskaya pl. 1, Voronezh 394006, E-mail: nupanteleeva@mail.ru

1 Зоологический институт Российской Академии наук, Унивесситетская наб. 1, С.-Петербург 199034, Россия.

${ }^{2}$ Воронежский государственный университет, Университетская пл. 1, Воронеж 394006, Россия.
}

KEY WORDS; Diptera, Chloropidae, Oscinellinae, host plants of larvae, Voronezh district.

КЛЮЧЕВЫЕ СЛОВА: двукрылые, злаковые мухи, Oscinellinae, кормовые растения личинок, Воронежская область.

ABSTRACT. Information is presented on host plants of 25 species of grass flies of the subfamily Oscinellinae (Chloropidae) in Voronezh province. Host plants are recorded for 7 species for the first time (marked by *), list of host plants are enlarged for other species. Two species were found to be secondary invaders of plants, other species - primary invaders of monocots.

РЕЗЮМЕ. Представлены данные о кормовых растениях личинок 25 видов злаковых мух подсемейства Oscinellinae (Chloropidae) в Воронежской области. Для 7 видов кормовые растения указываются впервые (отмечены звёздочкой), для остальных список кормовых растений расширен. Два вида фито-сапрофаги, развиваются в повреждённых растениях, остальные первичные фитофаги развиваются в живых однодольных растениях.

\section{Introduction}

Larvae of grass flies of the subfamily Oscinellinae (Chloropidae) are characterized by wide spectrum of alimentary association, develop in different substances and feed as mycetophagous, saprophagous, phytosaprophagous, phytophagous and carnivorous [Nartshuk, 2014]. Real phytophagous and many sapro-phytophagous larvae (secondary invaders) are usually associated with monocotyledonous plants. This paper presents some observations on host plants of phytophagous and saprophytophagous larvae of the subfamily Oscinellinae. Observations were made in Voronezh province of Russia in 2000-2013. Voronezh province occupied the centre of Central Russian Upland between Voronezh and Don Rivers. The main territory of Voronezh province lies in forest-steppen zone which is characterized by alternation of forb-steppe and broad-leaved forests. Southern part of Voronezh province lies in steppen zone. Flood-lands of rivers are occupied by meadows.

Some information of host-plants in Voronezh province was early published by Panteleeva in 2001 and 2007. Following method of rearing of flies was used: plants with rhizome were moved into laboratory, rhizome was placed into water, and part of plant was covered by plastic cowl. Flies were taken from cowl after flying out. Totally 99 specimens $\left(18 \sigma^{7}, 81\right.$ +) of flies were reared. Nomenclature of plants is done after Maevskyi [2006]. The present knowledge on the hostplants of considered species of Chloropidae are summarized in the Table.

\section{List of species}

1. Calamoncosis stipae Nartshuk, 1962.

Stipa capillata, S. lessingiana, S. zalesskii and S. pennata were cited as host plants [Nartshuk, 1962, 1972].

Adults (5) were reared from shoots of Stipa capillata, $S$. pennata, S. pulcherrima, collected on steppe near Divnogor'e.

2. Conioscinella frontella (Fallén, 1820).

Following host plants were indicated: Avena sativa, Hordeum vulgare, Anthoxantum odoratum, Avinella flexuosa, Dactylis glomerata, Deschampsia caespitosa, Festuca ovina, Elythria repens, Holcus lanatus, Phleum pratense, Secale sylvestre [Balachowski, Mesnil, 1935; Nye, 1958; Nartshuk, 1972; Karpova, 1972; Ufen, Chandler, 1978; Tschirnhaus, 1981, 1992; Krusteva, Beschovsky, 1998, 2000].

Adults (4) were reared from shoots of Brachypodium pinnatum and Poa nemoralis, taken on water meadows of the River Tikhaya Sosna near Ostrogozhsk, of the River Don near Belogor'e and of the River Chernaya Kalitva near Novaya Kalitva. 


\section{3. *Conioscinella livida Nartshuk, 1970.}

A female was reared from shoots of Poa nemoralis, taken on edge of Tallerman forest near Borisoglebsk. Host plant is indicated for the first time.

\section{4. *Conioscinella obscuripila Duda, 1933.}

Adults (2+) were reared from shoots of Brachypodium pinnatum è Poa nemoralis, taken on water meadows of the River Tikhaya Sosna near Ostrogozhsk, and of the River Chernaya Kalitva near Novaya Kalitva. Host plant is indicated for the first time.

\section{Conioscinella sordidella (Zetterstedt, 1848).}

Karpova [1972] recorded Elytrigia repens as host plant; Tschirnhaus [1992] - Agropyron sp.

Adults $\left(10^{7}, 5+\right)$ were reared from shoots of Phragmites australis, collected on fens near Ostrogozhsk, fens in Khrenvskoy bor and water meadow of Lake Ilmen' near Bogana.

\section{Eribolus nana (Zetterstedt, 1838).}

Valley et al. [1969] found larvae in shoots of Carex sp., infested by Cordilura varicornis Curran in USA. Nartshuk [1972] - in Carex sp., Scirpus sp., and Sparganium sp.

A female was reared from shoots of Carex acuta, taken on bog in Khrenvskoy bor near Duginka, secondary invaders.

\section{Microcercis trigonella (Duda, 1933).}

Following host plants were recorded: Glyceria fluitans, Festuca àrundinacea, Deschampsia caespitosa, Juncus effusum, J. gerrardii, Phalaroides arundinacea, Hypochaeris sp. [Rogocha, 1960; Tschirnhaus, 1981, 2007; Sharipov, 1991]

Adults (9) were reared from shoots of Agrostis capillaris, Elytrigia repens, Hordeum vulgare, Poa annua, Triticum durum, Zea mays, taken on forb steppe near Divnogor'e and Elan'-Koleno and on grass steppe near Krinitza, primary invaders.

\section{Oscinella alopecuri Mesnil, 1935.}

Host plants of this species is Alopecurus pratensis [Balachowsky, Mesnil, 1935; Nartshuk, 1956, 1972]. Rogocha [1960] listed also Lolium perennis.

Adults $\left(3 O^{7}, 4+\right)$ were reared from shoots of Alopecurus pratensis, collected on water meadows of the River Tikhaya Sosna near Divnogor'e and of the River Don near Belogor'e.

9. * Oscinella cariciphila Collin, 1946.

Collin [1946] named this species cariciphila as it occurs on Carex beds, but not reared from this plants.

Adults $\left(1 \mathrm{O}^{7}, 2+\right)$ were reared from shoots of Carex acuta, growing on bogging meadow of the River Usmanka near Krasnolesnyi. Host plant is indicated for the first time.

10. Oscinella festucae Mesnil, 1935.

Larvae of this species are primary invaders of shoots of Festuca pratensis, F. gigantea, Lolium perenne and Elymus sibiricus [Balachowsky, Mesnil, 1935; Nartshuk, 1956, 1972; Rogocha, 1960].

Adults (4+) were reared from shoots of Festuca gigantea, $F$. pratensis, F. rubra, taken on water meadows of the River Tikhaya Sosna near Divnogor'e and of the River Devitza near Strelitza.

\section{Oscinella frit (Linnaeus, 1758).}

Larvae of this species are primary invaders of shoots of different grasses and cereals and Avena spikelets.
Adults $\left(30^{7}, 5+\right)$ were reared from shoots of Agropyron cristatum, Agrostis capillaris, Avena sativa, Secale sylvestre, Triticum durum, Zea mays, collected on forb steppe, long fallow steppe near Divnogor'e and grass steppe near Krinitza.

12. Oscinella nigerrima (Macquart, 1835).

Triticum spp. and Phleum pratense were indicated as host plants of this species [Rygg, 1966, Nartshuk, 1972; Ufen, Chandler, 1978].

Adults (3) reared from shoots of Agrostis capillaris, collected on forb steppe near Verkhniy Karachan and Divnogor'e.

13. Oscinella nitidissima (Meigen, 1838).

Larvae of this species are phytophagous in shoots of many species of grasses, including several species of Agrostis [Nartshuk, 1956 (as Oscinella agrostis), 1972; Ufen, Chandler, 1978).

Adults $\left(10^{7}, 3+\right)$ were reared from shoots of Agrostis capillaris, taken on forb steppe near Divnogor'e and shoots of A. gigantea, taken on edge forest Khrenvskoy bor near Khrenovoe.

\section{Oscinella phlei Nartshuk, 1956.}

Larvae of this species are known as primary invaders of shoots of grasses of the genus Phleum [Nartshuk, 1956, 1972]. Karpova [1972] reported also Alopecuris pratensis as host plant.

Adults $\left(10^{\gamma}, 4+\right)$ were reared from shoots of Phleum pratense, taken on water meadows near Divnogor'e and Strelitza.

\section{Oscinella pusilla (Meigen, 1830).}

Larvae of this species are primary invaders of the grasses mostly of the tribe Triticeae, including cereals: wheat and barley.

Adults $\left(30^{7}, 4+\right)$ were reared from shoots of Elytrigia repens, Hordeum vulgare, Triticum durum, Zea mays, taken on forb steppe near Divnogor'e and Elan-Koleno.

\section{6. *Oscinella smirnovi Nartshuk, 1956.}

A female was reared from shoots of Agrostis gigantea, collected on fens in the forest Khrenvskoy bor near Duginka. Host plant is indicated for the first time.

\section{Oscinella vastator (Curtis, 1845).}

This species is considered as pest of wheat (Triticum spp.), develop also in shoots of Lolium perenne, L. multiflorum, Festuca rubra, F. pratensis, Phleum pretense [Ufen, Chandler, 1978].

Adults (2) were reared from shoots of Triticum aestivum and T. durum, taken on long fallow steppe near Divnogor'e.

\section{Oscinella ventricosi Nartshuk, 1956.}

Larvae of this species are phytophagous in shoots of Alopecurus ventricosus (Nartshuk, 1956).

Adults $\left(10^{\top}, 3+\right)$ were reared from shoots of Alopecurus arundinaceus and A. pratensis, collected on wet edge of the forest Usmanski bor near Shuberka and the Tallerman forest near Borisoglebsk.

\section{9. *Oscinella vindicata (Meigen, 1830).}

Adults (2+) were reared from shoots of Melica transsilvanica, taken on clearing in the forest Usmanski bor near Shuberka. Host plant is indicated for the first time. 


\section{Oscinimorpha albisetosa (Duda, 1933).}

Following host plants were reported: Elytrigia sp., Puccinelia sp. [Bärmann, Weipert, 1989].

A female was reared from shoots of Agrostis capillaris, taken on forb-grass steppe near Divnogor'e.

\section{1. *Oscinimorpha arcuata (Duda, 1932).}

A female reared from shoots of Agrostis capillaris taken on forb-grass steppe near Divnogor'e. Host plant is indicated for the first time.

\section{Oscinimorpha koeleriae (Nartshuk, 1970).}

Nartshuk [1972] reported Koeleria gracilis as host plant.

Adults (3⿻) were reared from shoots of Koeleria sclerophylla, growing on grass steppe (steppen zona) near Sukhoi Donez and Volokonovka.

\section{Oscinimorpha minutissima (Strobl, 1900).}

As host plants were indicated Oryza sp., Secale sp., Selene dioica and Salvia sclarea, two last plants are dicotiledonts [Nartshuk, 1972; Ufen, Chandler, 1978; Tschirnhaus, 1981, 2007], probably phyto-saprophag.

Adults (6+) were reared from shoots of Festuca ovina and $F$. vallesiaca, taken on forb-grass steppe near Divnogor'e and Elan'-Koleno and grass steppe (steppen zona) near Volokonovka.

\section{4. *Oscinimorpha sordidissima (Strobl, 1893).}

Adults $\left(4 \odot^{\top}, 4+\right.$ ) were reared from shoots of Briza media, Helictotrichon pratense, H. pubescens and Melica nutans, growing on edges and clearings of oak forest near Lipovka (the Boyarskyi forest), Vorontzovka (the Shipov forest) and the forest Usmanskyi bor near Shuberka. Host plant is indicated for the first time.

\section{Rhopalopterum atricorne (Zetterstedt, 1838).}

Nartshuk [1972] indicated Carex sp. as host plant (as Lioscinella platythorax Nartshuk, 1958); Ufen, Chandler [1978] - Eriophorum.

Adults (2) were reared from shoots of Carex acuta and C. riparia, taken on fens in the forest Khrenvskoy bor near Duginka.

\section{Conclusion}

Larvae of the most examined species are phytophagous - primary invaders of plants (23 species) and larvae of two species are phyto-saprophagous - secondary invaders of plants. Most examined Oscinellinae species have a wide list of hostplants but all belong to the family Poaceae. Two species $O$. cariciphila and $R$. atricorne are associated only with Cyperaceae. Microcercis trigonella has hostplants from two plant family: Poaceae and Juncaceae.

ACKNOWLEDGEMENTS. Authors are greatly indebted to Dr V.A Agafonov (Voronezh State University) for determining of vascular plants. For E.P. Nartshuk the study was performed in the frames of the state research project [AAAA-A17-117030310205-9].

\section{References}

Balachowski A.L., Mesnil L. 1935. Les insectes nuisibles aux plantes cultivées. Vol.1. Busson, Paris. P.1-1137.

Bärmann R., Weipert J. 1989. The chloropids (Diptera, Chloropidae) on lawn biotopes damaged by emission in the Saale valley near Jena (Thuringia): $\mathrm{XV}^{\text {th }}$ contribution to the study of the influence of air pollution on ecological systems // Beitrage zur Entomologie. Bd.39. S.279-318.

Collin J.E. 1946. The British genera and species of Oscinellinae // Transactions of the Royal Entomological Society of London. Vol.97. P.117-148.

Karpova A.I. 1972. [To ecologo-geographical characteristic of field fauna of grass flies (Diptera, Chloropidae)] // Entomologicheskoe obozrenie. Vol.51. No.4. P. 815-829 [in Russian].

Krusteva H.T., Beschovski V.L. 1998. Studies on the species composition of Diptera order internal stem pest and damages caused by them on spring barley // Acta zoologica Bulgarica. Vol.50. No.1. P.43-50.

Krusteva H.T., Beschovski V.L. 2000. Studies on the species composition of stem-boring dipterous pests and damages caused by their larvae on oats // Acta zoologica Bulgarica. Vol.52. No.3. P.29-36.

Maevskyi P.F. 2006. [Flora of the middle zona of the European parts of Russia]. M.: KMK Scientific Press. 600 pp. [in Russian].

Nartshuk E.P. 1956. [Species of the genus Oscinella (Diptera, Chloropidae) of European part of USSR and their host plants] // Entomologicheskoe obozrenie. Vol.35. No.4. P.856-882 [in Russian].

Nartshuk E.P. 1962.[A review of the palaearctic species of the genus Calamoncosis End. (Diptera, Chloropidae)] // Entomologicheskoe obozrenie. Vol.41. No.2. P.457-469. [English translation: Entomological review. 1962. Vol.41. No.2. P.281-288].

Nartshuk E.P. 1972. [Phytophagy in grassflies (Diptera, Chloropidae) and vector of its development] // 23 chteniya pamyati N.A. Kholodkovskogo. L.: Nauka. P.3-49 [in Russian].

Nartshuk E.P. 2014. [Larvae of grass flies (Chloropidae, Diptera): variety of habitats and food specialization] // Zoological journal. Vol.93. No.1. P.81-91. [English translation Entomological review. 2014. Vol.94. No.4. P.514-525].

Nyel W.B. 1958. The external morphology of some of the dipterous larvae living in the Gramineae of Brinain // Transactions of the Royal entomological Society of London. Vol.110. P.411-458.

Panteleeva N.Yu. 2001. [Diptera Brachycera of south-western part of Usmanskyi bor and their trophic associations] // Status and problems of ecosystems of middlerussian forest-steppe. Vyp.15. Voronezh, Voronezh State University. P.54-62 [in Russian].

Panteleeva N.Yu. 2007. [ New informations on trophic of phytophagous grassflies occurring in Central Chernozem'e] // Dostizheniya entomology on sluzhbe agropromyshlennogo kompleksa, lesnogo khosaistva i mediziny. Tesisy dokladov 13 s'ezda Russkogo entomologicheskogo obshchestva. Saint Petersburg. P.157-158 [in Russian].

Rogocha O.G. 1960. [Investigations on trophic associations of larvae of grass flies (Diptera, Chloropidae)]// Vrediteli selskokhozyaistvennykh kultur. Sbornik nauchnykh trudov. Kiev. Vol.10. P.102107 [in Ukrainian].

Rygg T. 1966. Species of Chloropidae (Diptera) on Gramineae in southeastern Norway // Norsk Entomologisk. Tidsskrift. Vol.13. P.160-162.

Sharipov Kh.G. 1981. [Insects injurios to Phalaroides arundinacea and Festuca arundinacea in Leningrad district] // Zashchita rasteniy. Sbornik nauchnykh trudov. Vol.405. P.20-25 [in Russian].

Tschirnhaus von M. 1981. Die Halm- und Minierfliegen im Grenzbereich Land-Meer der Nordsee. Eine Okologische Studie mit Beschreibung von zwei neuen Arten und neuen Fang- und Konservierungsmethoden (Diptera: Chloropidae et Agromyzidae) // Spixiana. Suppl.6. S.1-416.

Tschirnhaus von M. 1992. Minier - und Halmfliegen (Agromyzidae, Chloropidae) und 52 weitere Familien (Diptera) aus Malaise-Fallen in Kiesgruben und einen Vorsadtgarten in Köln // Decheniana. Beihefte (Bonn). Bd.31. S.445-497. 
Tschirnhaus von M. 2007. Acalyptrate Fliegen (Diptera: Schizophora,"Acalyptratae") der jungen Düneninseln Memmert und Mellum unter besoderer Berücksichtigung der Agromyzidae und Chloropidae // Drosera, Naturkundliche Mitteilungen aus Nordwestdeutschland. Hf.1/2. S.99-136.
Ufen R., Chandler P. 1978. Associations with plants. Higher plants // Stabbs A., P. Chandler (eds.). A dipterist's handbook. Amateur Entomologist. Vol.15. P.417-441.

Valley K., Wearsch T., Foote B.A. 1969. Larval feeding of certain Chloropidae // Proceedings of the Entomological Societe of Washington. Vol.71. No.1. P.29-34.

Table. Hostplanst of Oscinellinae (Chloropidae) species. Таблица. Кормовые растения видов Oscinellinae (Chloropidae).

Chloropidae (Oscinellinae)
species

Calamoncosis stipae Nartshuk, 1962

Conioscinella frontella (Fallén, 1820)

Conioscinella livida Nartshuk, 1970

Conioscinella obscuripila Duda, 1933

Conioscinella sordidella (Zetterstedt, 1848)

Eribolus nana (Zetterstedt, 1838)

Microcercis trigonella (Duda, 1933)

\begin{tabular}{|c|c|c|c|}
\hline $\begin{array}{l}\text { Host } \\
\text { plants }\end{array}$ & $\begin{array}{c}\text { Previously } \\
\text { known }\end{array}$ & $\begin{array}{c}\text { Herein } \\
\text { confirmed }\end{array}$ & $\begin{array}{l}\text { Newly } \\
\text { reported }\end{array}$ \\
\hline Stipa capillata & + & + & \\
\hline S. lessingiana & + & & \\
\hline S. pennata & + & + & \\
\hline S. pulcherrima & & & + \\
\hline S. zalesskii & + & & \\
\hline Anthoxantum odoratum & + & & \\
\hline Avena sativa & + & & \\
\hline Avinella flexuosa & + & & \\
\hline Brachypodium pinnatum & & & + \\
\hline Dactylis glomerata & + & & \\
\hline Deschampsia caespitosa & + & & \\
\hline Elytrigia repens & + & & \\
\hline Festuca ovina & + & & \\
\hline Holcus lanatus & + & & \\
\hline Hordeum vulgare & + & & \\
\hline Phleum pretense & & & + \\
\hline Poa nemoralis & + & & \\
\hline Secale sylvestre & + & & \\
\hline Poa nemoralis & & & + \\
\hline Brahypodium pinnatum & & & + \\
\hline Poa nemoralis & & & + \\
\hline Agropyron sp. & + & & \\
\hline Elytrigia repens & + & & \\
\hline Phragmites australis & & & + \\
\hline Carex acuta & & & + \\
\hline Carex sp. & + & & \\
\hline Scirpus sp. & + & & \\
\hline Sparganium sp. & + & & \\
\hline Glyceria fluitans & + & & \\
\hline Festuca arundinacea & + & & \\
\hline Deschampsia caespitosa & + & & \\
\hline Juncus effusum & + & & \\
\hline J. gerrardii & + & & \\
\hline Phalaroides arundinacea & + & & \\
\hline Hypochaeris sp. & + & & \\
\hline Agrostis capillaris & & & + \\
\hline Elytrigia repens & & & + \\
\hline Hordeum vulgare & & & + \\
\hline Poa аппиа & & & + \\
\hline Triticum durum & & & + \\
\hline Zea mays & & & + \\
\hline
\end{tabular}


Table. Continue.

Таблица. Продолжение.

Oscinella alopecuri Mesnil, 1935

Oscinella cariciphila Collin, 1946

Oscinella festucae Mesnil, 1935

Oscinella frit (Linnaeus, 1758)

Oscinella nigerrima (Macquart, 1835)

Oscinella nitidissima (Meigen, 1838)

Oscinella phlei Nartshuk, 1956

Oscinella pusilla (Meigen, 1830)

Oscinella smirnovi Nartshuk, 1956

Oscinella vastator (Curtis, 1845)

Oscinella ventricosi Nartshuk, 1956

Oscinella vindicata (Meigen, 1830)

Oscinimorpha albisetosa (Duda, 1933)
Alopecurus pratensis Lolium perennis

Carex acuta

Carex sp.

Festuca pratensis

$F$. gigantea

F. rubra

Elymus sibiricus

Lolium perenne

Agropyron cristatum

Agrostis capillaris

Avena sativa

Secale sylvestre

Triticum durum

Zea mays

Agrostis capillaris

Phleum pratense

Triticum spp.

Agrostis capillaris

A. gigantea

Agrostis spp.

Alopecurus pratensis

Phleum pratense

Phleum spp

Elytrigia repens

Hordeum vulgare

Triticum durum

Zea mays

Agrostis gigantea

Festuca rubra

F. pratensis

Lolium multiflorum

L. perenne

Phleum pretense

Triticum aestivum

T. durum

Alopecurus arundinaceus

A. pratensis

A. ventricosus

Melica transsilvanica

Agrostis capillaris

Elytrigia sp.

Puccinelia sp.

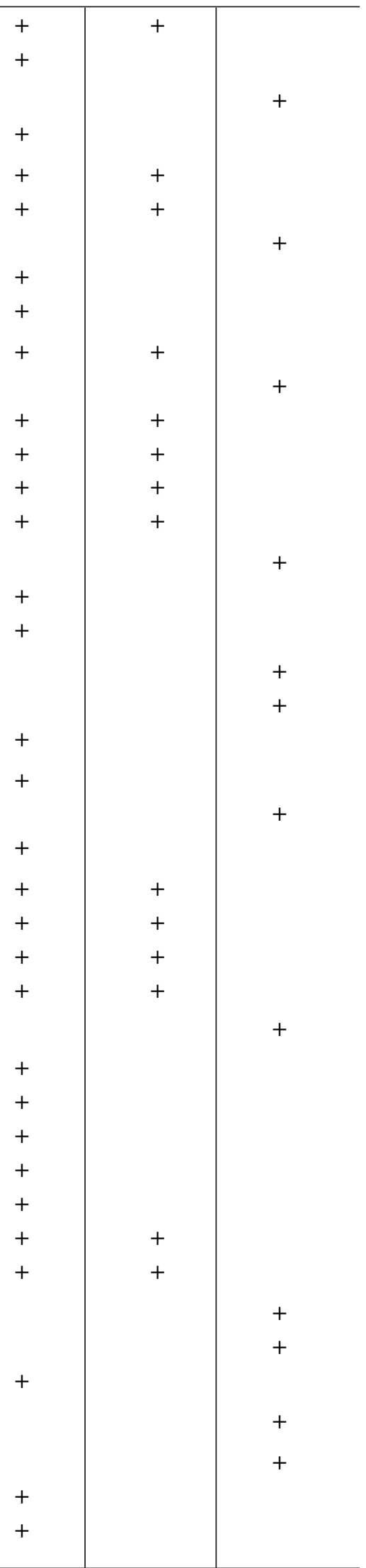


Table. Continue. Таблица. Продолжение.

\begin{tabular}{l|l|c|c}
\hline Oscinimorpha arcuata (Duda, 1932) & Agrostis capillaris & + \\
Oscinimorpha koeleriae (Nartshuk, 1970) & Koeleria gracilis & + & \\
Oscinimorpha minutissima (Strobl, 1900) & Festuca ovina & & + \\
F. vallesiaca & & + \\
Secale sp. & + & + \\
Oscinimorpha sordidissima (Strobl, 1893) & Selene dioica & + & + \\
Salvia sclarea & Briza media & + \\
Helictotrichon pratense & & + \\
H. pubescens & & + \\
Melica nutans & & + \\
\end{tabular}

